Article

\title{
The Effects of Electricity Production on Industrial Development and Sustainable Economic Growth: A VAR Analysis for BRICS Countries
}

\author{
Zhongdong Yu ${ }^{1}$, Wei Liu ${ }^{2, *}$, Liming Chen ${ }^{3}$, Serkan Eti ${ }^{4}{ }^{\circ}$, Hasan Dinçer ${ }^{4}(\mathbb{D}$ and \\ Serhat Yüksel ${ }^{4, *(D)}$ \\ 1 School of Management, GuangZhou University, GuangZhou 510006, China; mailyzd@gzhu.edu.cn \\ 2 School of Economics and Management, Zhengzhou Normal University, Zhengzhou 450044, China \\ 3 College of Finance and Statistics, Hunan University, Changsha 410082, China; chenliming@hnu.edu.cn \\ 4 The School of Business, İstanbul Medipol University, İstanbul 34815, Turkey; seti@medipol.edu.tr (S.E.); \\ hdincer@medipol.edu.tr (H.D.) \\ * Correspondence: liuwei@zznu.edu.cn (W.L.); serhatyuksel@medipol.edu.tr (S.Y.)
}

Received: 19 September 2019; Accepted: 14 October 2019; Published: 23 October 2019

\begin{abstract}
This study aims to evaluate the effect of electricity production on industrial development and sustainable economic growth. In this context, Brazil, Russia, India, China, and South Africa (BRICS), countries which have the highest increase in electricity production in the period of 2000-2018, are included in the scope of this study. Annual data of these variables in the period of 1991-2018 are used and three different models are created by using Vector Auto Regression (VAR) methodology. The findings state that electricity production in BRICS countries has a positive effect on both industrial production and sustainable economic growth. Hence, electricity production needs to be increased for them. For this purpose, it is important to encourage investors with tax advantages, location orientation and financing. Moreover, BRICS countries should give importance to renewable energy investments in order to increase electricity production. These issues have a contributing effect to sustainable economic growth.
\end{abstract}

Keywords: sustainability; electricity; sustainable economic growth; industry; BRICS

\section{Introduction}

Energy has been an important part of human life for centuries. The main reason for this is that energy is used in all areas of life such as heating, cooling and transportation. Furthermore, energy is vital for the development of a country [1]. Considering the above, it is not possible to give up energy consumption. Energy can be obtained from non-renewable sources such as oil, coal and natural gas. In addition, renewable energy sources such as wind, solar and geothermal are also considered as alternative sources in energy production [2-4]. Therefore, countries aim to provide the energy they have to consume at the lowest possible cost $[5,6]$. In order to achieve this goal, a significant majority of countries have energy policies in order to provide sustainability in their economic growth.

Electrical energy has an important role in progress in both social and economic terms. It is considered as one of the important inputs of industrial production. In this context, it is thought that electricity generation plays a vital role in increasing the industrial volume [7]. In addition to its contribution to industry, electrical energy is also very important in order to meet the daily needs of citizens. Taking these issues into consideration, electricity generation is expected to increase sustainable economic growth. Moreover, if the generated electricity cannot be used effectively in the country, it will not contribute to sustainable economic growth [8]. 
According to statistics published by the World Bank, there is an increase of approximately $3 \%$ in electricity production worldwide in the period of 2000-2018. While this ratio is approximately $0.8 \%$ for The Organization for Economic Co-operation and Development (OECD), electricity production has increased by $0.4 \%$ in the Group of Seven (G7) countries, which constitute the world's seven largest economies. On the other hand, this ratio is only $0.4 \%$ in European Union countries. As can be understood from these issues, all of these countries produce electricity at a rate below the world average. On the other hand, in Brazil, Russia, India, China, and South Africa (BRICS) economies, electricity production went up by $6.7 \%$ in the related period. If electricity is used effectively, it is thought that this situation will positively affect sustainable economic growth.

In this study, it is investigated whether electricity production in BRICS countries has an effect on industrial production and sustainable economic growth. Annual data of these variables in the period of 1991-2018 are taken into consideration. Additionally, a Vector Auto Regression (VAR) model was established by considering these three variables. As mentioned earlier, BRICS countries have the highest increase in electricity production in the period of 2000-2018. Therefore, it will be possible to determine the role of electricity production on industrial development and sustainable economic growth.

This study is thought to contribute to the literature in many respects. Firstly, there are limited studies examining the impact of electricity generation on industry and sustainable economic growth together. Studies generally focus on the relationship between electricity generation and one of these variables. In addition, the effect of electricity generation on these two variables was taken into consideration for the first time in BRICS countries. On the other hand, taking into account the VAR method in the analysis process of this study, the bidirectional relationship between the variables could be measured.

This study consists of five different sections. This section, where general information about the subject is shared, constitutes the first part of this study. In the second part, current studies in the literature examining the relationship between electricity production, sustainable economic growth and industrial development are shared. On the other hand, theoretical information about the VAR model is included in the third part of this study. In addition, in the fourth section, the details of the model established by the VAR method are given. Finally, analysis results and recommendations are shared.

\section{Literature Review}

The effects of electrical energy on different factors were frequently studied. In the majority of studies, the effect of electricity consumption on economic growth was examined. In these studies, it is generally emphasized that electricity consumption increases economic growth. As an example, Salahuddin and Alam [9] examined Gulf Cooperation Council (GCC) countries with the dynamic ordinary least squares method and emphasized that electricity consumption has an important influence on economic growth. Kahouli [10], Afzal et al. [11] and Asumadu-Sarkodie and Owusu [12] applied the same method for different countries and reached similar results. On the other hand, Liu et al. [13] also reported that a causal relationship is identified between these factors using Granger and Toda Yamamoto causality analyzes. In addition, Iyke [14], Mezghani and Haddad [15], Sbia et al. [16] and Ibrahiem [17] also took this issue into consideration using different methods such as the Vector Error Correction Model (VECM), Johansen Cointegration and the Autoregressive Distributed Lag Bound Test (ARDL). As a result, they concluded that there is a positive and long-term relationship among these variables.

In addition to the aforementioned studies, in some studies, there is a two-way relationship between electricity consumption and economic growth. For instance, Churchill and Ivanovski [18] conducted an analysis of the consumption of electricity in Australia using the ARDL method. According to the results of the analysis, it was determined that there is a two-way causality between economic growth and electricity consumption. In parallel with this study, Shahbaz et al. [19] examined 157 different countries with the help of Pedroni cointegration analysis. As a result, they claimed that there was a 
two-way relationship between electricity consumption and Gross Domestic Product (GDP). On the other hand, Al-Mulali and Che Sab [20] conducted a study on GCC and Middle East countries with different methods. In these studies, a two-way causality was found between economic development and electricity consumption.

However, in some studies, it was concluded that electricity consumption did not affect economic growth. As an example, Karanfil and Li [21] tried to evaluate this relationship for 160 different countries. In the analysis process, VECM methodology was considered. As a result, for some of them, it is concluded that there is no relationship between economic growth and electricity consumption. This result is also identified by Zhang et al. [22] for China. On the other hand, Sarwar et al. [23] conducted a study on 210 different countries using the panel VAR method. It was found that electricity consumption of countries that use non-renewable resources such as coal and oil to produce electricity has a negative relationship with economic growth. In parallel with the mentioned studies, Cowan et al. [24] also took into account different countries such as Albania and South Africa in their studies. They determined that there was no causality between electricity consumption and economic growth.

In the literature, there are also some studies on electricity generation. Some of them have analyzed the relationship between electricity production and economic growth. Bento and Moutinho [25] examined the efficiency of electricity generation in Italy. In this study using Granger causality analysis, it was concluded that there is a positive relationship between electricity production and economic growth. In addition, Dyrstad et al. [26], Awad and Yossof [27] and Magalie and Pacific [28] also analyzed different countries such as OECD, Sudan and Cameroon. In these studies, they stated that electricity production in the short term increases economic growth, but this effect is not bi-directional. On the other hand, Vera and Kristjanpoller [29] examined Latin American countries with panel cointegration analysis. In this study, it has been determined that electricity production affects GDP in the long run, but not in the short term.

Some researchers have focused on the impact of electricity generation on industrial development. These studies are quite limited in the literature and similar results have been reached in general. For example, Sgobba and Meskell [30] conducted a study of this relationship on Ireland. In the analysis stage of this study, simulation technique was used. As a result, it has been determined that the increase in electricity production contributes very positively to industrial development. On the other hand, Forsberg et al. [31], Mata-Torres et al. [32] and Morakabatchiankar et al. [33] also reached similar results by taking into account the optimization method in their studies.

This shows that there are many studies about electrical energy. While most of these studies take energy consumption into consideration, energy production is emphasized in fewer studies. One-way relationship was taken into consideration in the majority of studies. It is thought that an analysis that considers the two-way relationship will contribute to the literature. Additionally, it is also understood that there is a need for a new evaluation which uses energy production instead of energy consumption. Hence, this study focuses on the relationship between energy production with sustainable economic growth and industrial production. Additionally, by creating three different models with VAR methodology, a two-way relationship can be considered. Therefore, it is believed that this work will complete this deficiency mentioned in the literature.

\section{VAR Method}

The VAR method aims to determine the relationship between two or more variables. Similar models in the literature only examine a one-way relationship. Therefore, the biggest difference of this model from other approaches is that it takes into account the bi-directional relationship. In addition, it also includes aspects such as effect-response functions and a variance separation table. With the help of these issues, it is possible to make a more detailed analysis while finding the relationship between the variables. The standard state of a two-variable VAR model is given in the Equations (1) and (2). 


$$
\begin{aligned}
& y_{t}=a_{1}+\sum_{i=1}^{p} b_{1 i} y_{t-i}+\sum_{i=1}^{p} b_{2 i} x_{t-i}+v_{1 t} \\
& x_{t}=c_{1}+\sum_{i=1}^{p} d_{1 i} y_{t-i}+\sum_{i=1}^{p} d_{2 i} x_{t-i}+v_{2 t}
\end{aligned}
$$

In the above equations, $x_{t}$ and $y_{t}$ show the variables that are subject to the relationship. In Equation (1), $y_{t}$ is dependent and $x_{t}$ is independent, which is the opposite for Equation (2). On the other hand, $b_{1}, b_{2}, d_{1}$ and $d_{2}$ also express the coefficients of the independent variables. In addition, $v_{1}$ and $v_{2}$ represent error terms. The value $p$ represents the ideal length of the model's delays. Additionally, $\mathrm{a}_{1}$ and $c_{1}$ indicate constant terms.

There are some steps in the process of establishing a VAR model. First, the variables subject to the analysis should be stationary. For this purpose, in the first instance, the variables are subjected to stationary analysis. In this process, stationary forms of the variables are used [34]. After stationarity analysis, it is necessary to examine whether the variables are autocorrelated or equal variances. After successful completion of this stage, the appropriate lag length needs to be determined. In this process, information criteria are taken into consideration. The final step in the VAR analysis established according to the determined lag length is the interpretation of the obtained models [35]. There are lots of studies in the literature in which VAR analysis was taken into consideration. For example, Afonso et al. [36], Jasper [37] and Gnimassoun and Mignon [38] considered this methodology for financial and economic issues. On the other hand, Pardon et al. [39] conducted a study with VAR methodology to make an analysis about the health industry. In addition to them, Charfeddine [40] used the VAR method to identify some issues in energy industry.

\section{An Application on BRICS Countries}

In this study, the effect of electricity production in BRICS countries on industrial production and sustainable economic growth is examined. According to the World Bank data, BRICS are the countries that increased their electricity production the most in the period of 2000-2018. In order to achieve the aim of this study, three different variables are considered. With respect to the variable of sustainable economic growth, the annual increase in GDP level is taken into consideration. On the other hand, regarding industrial production variable, industry volume data including construction is used. In addition, as for electricity production variable, the increase rate is considered.

For all three variables, the total values of the BRICS countries are calculated first. Then, the increase rates of these variables compared to the previous period are determined and these values are used in the analysis. On the other hand, annual data for the period of 1991-2018, which is the largest range of data available for these variables, is considered.

In the process of constructing the VAR model, firstly, a unit root test was performed for three different variables. In this process, the Augmented Dickey Fuller (ADF) unit root test was considered. The results of the analysis are shared in Table 1.

\begin{tabular}{|c|c|c|c|}
\hline Variable & ADF Test Level & P Value & Result \\
\hline \multirow{2}{*}{ Electricity Production } & 0-Level & 0.1031 & \multirow{2}{*}{ It is stationary in its first difference } \\
\hline & 1-Level & 0.0000 & \\
\hline \multirow{2}{*}{ Industrial Production } & 0-Level & 0.0541 & \multirow{2}{*}{ It is stationary in its first difference } \\
\hline & 1-Level & 0.0003 & \\
\hline \multirow{2}{*}{ Economic Growth } & 0-Level & 0.0880 & \multirow{2}{*}{ It is stationary in its first difference } \\
\hline & 1-Level & 0.0000 & \\
\hline
\end{tabular}

Table 1. Augmented Dickey Fuller (ADF) Test Results. 
When $\mathrm{p}$ values are lower than 0.05 , it means that the variables are stationary. Table 1 indicates that all variables are not stationary on their level values because their values are greater than 0.05 . On the other hand, $p$ values of the first differences of these variables are lower than 0.05 so that it is understood that these variables become stationary in their first differences. In the VAR model, the stationary forms of these variables are used. After stationarity analysis, it is necessary to examine whether there is autocorrelation in the variables. In this context, Lagrange multiplier (LM) statistics were used. The results are shared in Table 2.

Table 2. Lagrange multiplier (LM) Test Results.

\begin{tabular}{ccc}
\hline Lags & LM Stat & Probability \\
\hline 1 & 7.234300 & 0.6127 \\
\hline 2 & 7.123986 & 0.6242 \\
\hline 3 & 8.121445 & 0.5220 \\
\hline 4 & 13.64941 & 0.1354 \\
\hline 5 & 7.885205 & 0.5458 \\
\hline 6 & 11.94059 & 0.2167 \\
\hline 7 & 4.659839 & 0.8629 \\
\hline 8 & 3.886649 & 0.9187 \\
\hline 9 & 6.095947 & 0.7303 \\
\hline 10 & 10.24229 & 0.3312 \\
\hline 11 & 7.059946 & 0.6309 \\
\hline 12 & 10.05900 & 0.3457 \\
\hline
\end{tabular}

When the probability values are greater than 0.05 , it gives information that there is no autocorrelation. Hence, Table 2 indicates that this VAR model has no autocorrelation problem because probability values of 12 different lags are greater than 0.05 . Another important condition of VAR methodology is that there should not be heteroscedasticity. For this purpose, the White test is taken into consideration. The results of this test are illustrated in Table 3.

Table 3. White Test Results.

\begin{tabular}{ccc}
\hline Chi-Square Test & Degree of Freedom & Probability \\
\hline 73.25190 & 72 & 0.4367 \\
\hline
\end{tabular}

Because the probability value stated in Table 3 is greater than 0.05 , it is shown that this model does not have any heteroscedasticity problem. Another precondition of VAR methodology is that there should be normality. In this context, the Jarque-Bera test is used and the results are given on Table 4 .

Table 4. Analysis Results of Normality.

\begin{tabular}{cccc}
\hline Component & Jarque-Bera & df & Probability \\
\hline 1 & 1.825265 & 2 & 0.4015 \\
\hline 2 & 1.246925 & 2 & 0.5361 \\
\hline 3 & 0.892260 & 2 & 0.6401 \\
\hline Joint & 3.964450 & 6 & 0.6815 \\
\hline
\end{tabular}

The probability values in Table 4 are greater than 0.05 , so it is concluded that this VAR model satisfies the normality condition. First of all, optimal lag length is defined in the generation of the VAR model. For this purpose, different information criteria are used, such as Akaike Information Criterion (AIC), Schwarz Criterion (SC), Lag Ratio (LR), Final Prediction Error (FPE) and Hannan Quinn (HQ). The results are demonstrated in Table 5 . 
Table 5. Vector Auto Regression (VAR) Lag Length Determination Criteria.

\begin{tabular}{cccccc}
\hline Lag & LR & FPE & AIC & SC & HQ \\
\hline 0 & NA & $3.59 \times 10^{-10}$ & -13.23341 & -13.08530 & -13.19616 \\
\hline 1 & $32.71376^{*}$ & $1.42 \times 10^{-10}$ & -14.17258 & $-13.58015^{*}$ & -14.02358 \\
\hline 2 & 16.84383 & $1.14 \times 10^{-10}$ & $-14.44271^{*}$ & -13.40595 & $-14.18197^{*}$ \\
\hline 3 & 5.395191 & $1.86 \times 10^{-10}$ & -14.07512 & -12.59404 & -13.70263 \\
\hline 4 & 8.829809 & $2.20 \times 10^{-10}$ & -14.17549 & -12.25008 & -13.69125 \\
\hline \multicolumn{5}{c}{ *It defines optimal lag length. }
\end{tabular}

Table 5 defines that most of the information criteria (FPE, AIC, HQ) show that the optimal lag length is 2. After determining the ideal lag length, the VAR model is constructed. According to the results of this model, which variables affect each other can be determined. In this study, since there are three different variables (electricity generation, industrial production and sustainable economic growth), three different models have been formed. On the other hand, since the ideal delay length is determined as 2, the maximum second delay value of each variable is included in the model as an independent variable. The details of these three models are summarized in Table 6.

Table 6. The Details of Three Different VAR Models.

\begin{tabular}{|c|c|c|c|c|}
\hline \multirow{2}{*}{ Variables } & & Model 1 & Model 2 & Model 3 \\
\hline & & $\begin{array}{c}\text { Electricity } \\
\text { Production (EP) }\end{array}$ & $\begin{array}{l}\text { Economic Growth } \\
\text { (EG) }\end{array}$ & $\begin{array}{c}\text { Industrial } \\
\text { Production (IP) }\end{array}$ \\
\hline \multirow{3}{*}{$\begin{array}{l}\text { Electricity Production } \\
\qquad(-1)\end{array}$} & Coefficient & 0.107452 & 0.427427 & 2.234936 \\
\hline & Standard Error & $(0.27760)$ & $(0.20852)$ & $(0.98274)$ \\
\hline & $\mathrm{t}$ statistics & [0.38708] & [2.04985] & [2.27418] \\
\hline \multirow{3}{*}{$\begin{array}{l}\text { Electricity Production } \\
\qquad(-2)\end{array}$} & Coefficient & -0.612204 & -0.230908 & -0.615853 \\
\hline & Standard Error & $(0.32148)$ & $(0.24148)$ & $(1.13809)$ \\
\hline & t statistics & {$[-1.90433]$} & {$[-0.95623]$} & {$[-0.54113]$} \\
\hline \multirow{3}{*}{ Economic Growth (-1) } & Coefficient & -0.646485 & -0.334810 & 0.572310 \\
\hline & Standard Error & $(0.46765)$ & $(0.35127)$ & $(1.65555)$ \\
\hline & $\mathrm{t}$ statistics & {$[-1.38241]$} & {$[-0.95314]$} & [0.34569] \\
\hline \multirow{3}{*}{ Economic Growth (-2) } & Coefficient & -0.569922 & 0.088008 & -1.769981 \\
\hline & Standard Error & $(0.49853)$ & $(0.37447)$ & $(1.76488)$ \\
\hline & $\mathrm{t}$ statistics & {$[-1.14320]$} & [0.23502] & {$[-1.00289]$} \\
\hline \multirow{3}{*}{ Industrial Production (-1) } & Coefficient & 0.074637 & -0.045868 & -0.359703 \\
\hline & Standard Error & $(0.09027)$ & $(0.06781)$ & $(0.31958)$ \\
\hline & $\mathrm{t}$ statistics & [0.82680] & {$[-0.67644]$} & {$[-1.12556]$} \\
\hline \multirow{3}{*}{ Industrial Production (-2) } & Coefficient & 0.131344 & 0.027548 & 0.145997 \\
\hline & Standard Error & $(0.07946)$ & $(0.05969)$ & $(0.28130)$ \\
\hline & $\mathrm{t}$ statistics & [1.65293] & [0.46155] & [0.51900] \\
\hline \multirow{3}{*}{ Constant } & Coefficient & 0.003954 & 0.001731 & 0.005062 \\
\hline & Standard Error & $(0.00430)$ & $(0.00323)$ & $(0.01523)$ \\
\hline & t statistics & [0.91924] & {$[0.53564]$} & [0.33242] \\
\hline R-square & & 0.482764 & 0.372919 & 0.612397 \\
\hline Adjusted R-square & & 0.310352 & 0.163892 & 0.483196 \\
\hline Durbin Watson Statistic & & 1.90 & 1.97 & 1.85 \\
\hline F Statistics (probability) & & 0.00 & 0.00 & 0.00 \\
\hline
\end{tabular}

On the other hand, the equations of these three different models are given in the Equations (3)-(5). 


$$
\begin{gathered}
E P_{t}=C 1 * E P_{t-1}+C 2 * E P_{t-2}+C 3 * E G_{t-1}+C 4 * E G_{t-2}+C 5 * I P_{t-1}+C 6 * I P_{t-2}+C 7 \\
E G_{t}=C 8 * E P_{t-1}+C 9 * E P_{t-2}+C 10 * E G_{t-1}+C 11 * E G_{t-2}+C 12 * I P_{t-1}+C 13 * I P_{t-2}+C 14 \\
I P_{t}=C 15 * E P_{t-1}+C 16 * E P_{t-2}+C 17 * E G_{t-1}+C 18 * E G_{t-2}+C 19 * I P_{t-1}+C 20 * I P_{t-2}+C 21
\end{gathered}
$$

All probability values of $\mathrm{F}$ statistics in Table 6 are lower than 0.05 . This situation gives information that all these three VAR models are statistically significant. After the significance test of the model, it is necessary to determine whether the variables in the models are significant. In this context, probability

\begin{tabular}{|c|c|c|c|c|c|}
\hline Model & $\begin{array}{l}\text { Dependent } \\
\text { Variables }\end{array}$ & $\begin{array}{l}\text { Independent } \\
\text { Variables }\end{array}$ & $\begin{array}{l}\text { Symbol of } \\
\text { Independent } \\
\text { Variables }\end{array}$ & Coefficient & Probability \\
\hline \multirow{7}{*}{ Model 1} & \multirow{7}{*}{ EP } & $\mathrm{EP}(-1)$ & C (1) & 0.107452 & 0.7002 \\
\hline & & $\mathrm{EP}(-2)$ & $C(2)$ & -0.612204 & 0.0622 \\
\hline & & EG (-1) & C (3) & -0.646485 & 0.1725 \\
\hline & & EG (-2) & C (4) & -0.569922 & 0.2580 \\
\hline & & $\operatorname{IP}(-1)$ & C (5) & 0.074637 & 0.4120 \\
\hline & & $\operatorname{IP}(-2)$ & $C(6)$ & 0.131344 & 0.1041 \\
\hline & & Constant Term 1 & $C(7)$ & 0.003954 & 0.3621 \\
\hline \multirow{7}{*}{ Model 2} & \multirow{7}{*}{ EG } & $\mathrm{EP}(-1)$ & $C(8)$ & 0.427427 & 0.0452 \\
\hline & & $\mathrm{EP}(-2)$ & C (9) & -0.230908 & 0.3432 \\
\hline & & EG (-1) & $C(10)$ & -0.334810 & 0.3448 \\
\hline & & EG (-2) & C (11) & 0.088008 & 0.8151 \\
\hline & & $\operatorname{IP}(-1)$ & C (12) & -0.045868 & 0.5016 \\
\hline & & $\operatorname{IP}(-2)$ & C (13) & 0.027548 & 0.6463 \\
\hline & & Constant Term 2 & C (14) & 0.001731 & 0.5944 \\
\hline \multirow{7}{*}{ Model 3} & \multirow{7}{*}{ IP } & $\mathrm{EP}(-1)$ & C (15) & 2.234936 & 0.0270 \\
\hline & & $\mathrm{EP}(-2)$ & C (16) & -0.615853 & 0.5906 \\
\hline & & EG (-1) & C (17) & 0.572310 & 0.7309 \\
\hline & & EG (-2) & C (18) & -1.769981 & 0.3204 \\
\hline & & $\operatorname{IP}(-1)$ & C (19) & -0.359703 & 0.2653 \\
\hline & & $\operatorname{IP}(-2)$ & $C(20)$ & 0.145997 & 0.6059 \\
\hline & & Constant Term 3 & $C(21)$ & 0.005062 & 0.7409 \\
\hline
\end{tabular}
values of coefficients are considered. Table 7 shows the statistical results of the variables.

Table 7. Coefficients Statistics of VAR Models.

In order for a variable to be statistically significant, probability values should be lower than 0.05 . Table 7 indicates that for the model 1, no variables can satisfy this condition. In addition to this issue, with respect to the model 2, the probability value of the variable EP $(-1)$ is lower than 0.05 . In this model, the dependent variable is EG and the coefficient of EP (-1) is 0.427427 . This situation gives information that the increase in electricity production will contribute to sustainable economic growth in the following period. On the other hand, in model 3, IP is the dependent variable. In this model, only the probability value of the independent variable EP $(-1)$ is lower than 0.05 . This issue identifies 
that this variable is statistically significant. Because the coefficient of this variable is 2.234936 , it is concluded that an increase in electricity production will have a positive effect on industrial production in the following period.

Following the establishment of the VAR model, another issue that needs to be tested is whether this model is stationary or not. In this context, for the model to be stationary, the eigenvalues of the coefficient matrix of this model must remain within the unit circle. Figure 1 illustrates this situation.

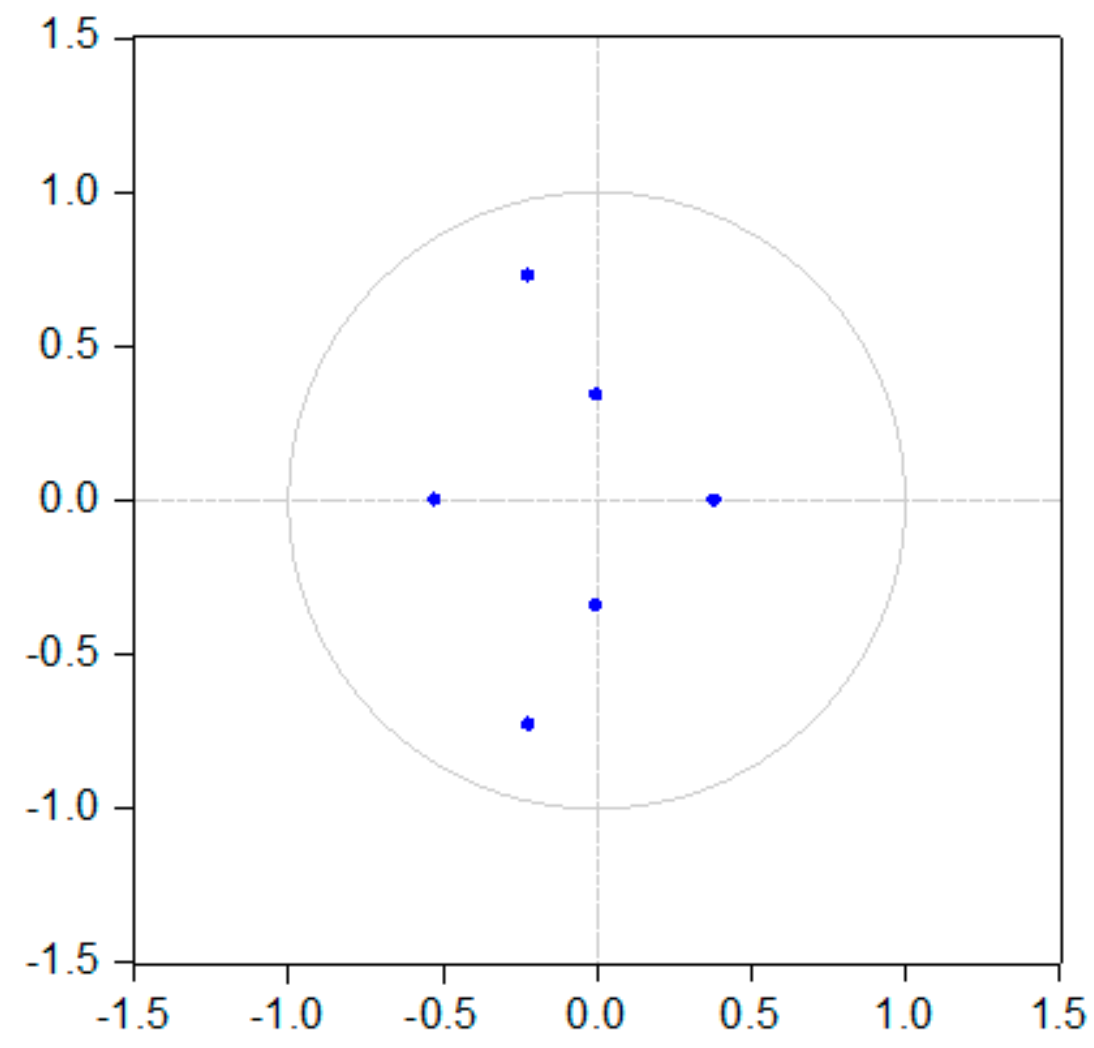

Figure 1. VAR Model Stability Chart.

Figure 1 shows that the eigenvalues of the model remain within the unit circle. This indicates that the VAR model is stationary. In a more detailed interpretation of the variables in the VAR model, impulse-response graphs should be examined. With the help of these functions of VAR models, the effect of a standard error shock on another variable can be seen. Impulse-response graphs are stated in Appendix A. While evaluating these graphs, it is identified that economic growth and industrial production give significant responses to the changes in electricity production.

Once the VAR model is established, another issue to consider is the periodic separation of the variances of the variables. For this purpose, variance decomposition tables are created for all three different variables. Table 8 gives information about the variance decomposition table for the variable of electricity production. 
Table 8. Variance Decomposition Table for EP.

\begin{tabular}{cccc}
\hline Period & EP & EG & IP \\
\hline 1 & 100.0000 & 0.000000 & 0.000000 \\
\hline 2 & 95.77333 & 1.542738 & 2.683929 \\
\hline 3 & 90.14635 & 1.675937 & 8.177714 \\
\hline 4 & 88.66761 & 1.635394 & 9.697000 \\
\hline 5 & 86.41934 & 3.248721 & 10.33194 \\
\hline 6 & 85.08541 & 3.387580 & 11.52701 \\
\hline 7 & 84.93269 & 3.566776 & 11.50053 \\
\hline 8 & 84.42381 & 3.720599 & 11.85560 \\
\hline 9 & 84.36638 & 3.718579 & 11.91504 \\
\hline 10 & 84.23517 & 3.800070 & 11.96476 \\
\hline
\end{tabular}

Table 8 demonstrates that the variable of electricity production is basically explained by itself. On the other hand, Table 9 indicates the variance decomposition table for the variable of economic growth.

Table 9. Variance Decomposition Table for EG.

\begin{tabular}{cccc}
\hline Period & EP & EG & IP \\
\hline 1 & 70.39180 & 29.60820 & 0.000000 \\
\hline 2 & 64.56056 & 33.74607 & 1.693377 \\
\hline 3 & 64.13027 & 29.10670 & 6.763027 \\
\hline 4 & 63.90133 & 29.10961 & 6.989052 \\
\hline 5 & 63.79256 & 28.11563 & 8.091814 \\
\hline 6 & 63.74214 & 27.68483 & 8.573025 \\
\hline 7 & 63.58844 & 27.75450 & 8.657061 \\
\hline 8 & 63.51788 & 27.52714 & 8.954982 \\
\hline 9 & 63.49857 & 27.54639 & 8.955041 \\
\hline 10 & 63.47139 & 27.49484 & 9.033773 \\
\hline
\end{tabular}

Table 9 states that economic growth is mainly explained by electricity production. Hence, it is understood that for BRICS countries, electricity production has a very important influence on sustainable economic growth. Moreover, Table 10 gives information about the variance decomposition table for the variable of industrial production.

Table 10 demonstrates that electricity production is the most important variable to explain industrial production. In other words, electricity production in BRICS countries leads to industrial production. 
Table 10. Variance Decomposition Table for IP.

\begin{tabular}{cccc}
\hline Period & EP & EG & IP \\
\hline 1 & 32.50868 & 26.45660 & 41.03472 \\
\hline 2 & 44.86773 & 20.70473 & 34.42755 \\
\hline 3 & 55.20351 & 16.77596 & 28.02053 \\
\hline 4 & 53.47852 & 19.41293 & 27.10856 \\
\hline 5 & 53.69435 & 18.69059 & 27.61506 \\
\hline 6 & 53.59788 & 18.69126 & 27.71086 \\
\hline 7 & 53.78758 & 18.54912 & 27.66331 \\
\hline 8 & 53.85252 & 18.37414 & 27.77334 \\
\hline 9 & 53.81098 & 18.46101 & 27.72801 \\
\hline 10 & 53.83560 & 18.39542 & 27.76897 \\
\hline
\end{tabular}

\section{Discussion and Conclusion}

In this study, the effect of electricity production on sustainable economic growth and industrial production is analyzed. In this context, BRICS countries are included in the scope of the review. They are the countries with the highest increase in electricity production in the period of 2000-2018. In the analysis process of this study, three different models were established by using the VAR method. For this purpose, annual data of these variables in the period of 1991-2018 are taken into consideration.

According to the results of the analysis, the increase in electricity production will contribute to the sustainable economic growth in the following period. On the other hand, it is also identified that higher electricity production will have a positive effect on industrial production in the following period. In summary, it is concluded that electricity production has a significant impact on both sustainable economic growth and industrial production for BRICS countries.

As can be seen from the results of this study, electricity generation is vital for both industrial production and sustainable economic growth. Therefore, electricity production needs to be increased especially for BRICS countries. The main reason for this is that they have the status of developing countries. The most important objective for them is to reach the level of developed countries, since economic development, among other factors, can improve population health status [41-43]. Hence, electricity generation is thought to serve this purpose seriously. Within this framework, it is thought that the most significant duty belongs to the governments in these countries. For example, it would be appropriate to give the necessary incentives for the construction of the dam. For this purpose, it is important to encourage investors with tax advantages, location orientation and financing. By increasing the number of the dams, it can be possible to increase electricity production, which has a positive contribution to sustainable growth.

In addition to these issues, it is also important that these countries turn to alternative energy sources in order to increase electricity production. For instance, renewable energy sources such as solar, wind and geothermal energy have gained importance especially in recent years $[44,45]$. These energy alternatives have an inexhaustible structure because they take their resources from nature. On the other hand, these alternative energy sources have no negative impact on the environment [46]. Because of these issues, BRICS countries should turn to renewable energy investments. For this purpose, it is important to provide financial support to investors, such as tax advantage and providing loans. Thus, it will be possible to achieve sustainable electricity production and sustainable economic growth by using renewable energy sources.

It is also recommended that countries should give importance to electricity production. Another important point is that a detailed plan should be designed by the authorities with the aim of using this electricity effectively. This situation is essential especially for developing countries. Because they aim 
to improve their economies in order to reach the status of a developed economy, they should mainly focus on electricity production and use it effectively. In this study, BRICS countries are selected because they have the highest ratio in electricity production. The most important limitation of this study is the scope because of the data availability problem. However, in future studies, if all necessary data can be provided, different countries or country groups can be considered, such as G7, E7 or European Union.

Author Contributions: Conceptualization, Z.Y. and S.E.; Methodology, S.Y.; Software, W.L.; Validation, H.D., L.C. and S.Y.; Formal Analysis, S.E.; Investigation, Z.Y.; Resources, S.Y.; Data Curation, Z.Y.; Writing-Original Draft Preparation, W.L.; Writing-Review \& Editing, L.C.; Visualization, S.Y.; Supervision, H.D.; Project Administration, H.D.; Funding Acquisition, Z.Y.

Funding: This research was funded by [Philosophy and Social Science Plan Project of Henan Province, China] grant number [2019BJJ013].

Acknowledgments: This work was sponsored in part by the Philosophy and Social Science Plan Project of Henan Province, China (2019BJJ013).

Conflicts of Interest: The authors declare no conflict of interest.

\section{Appendix A}

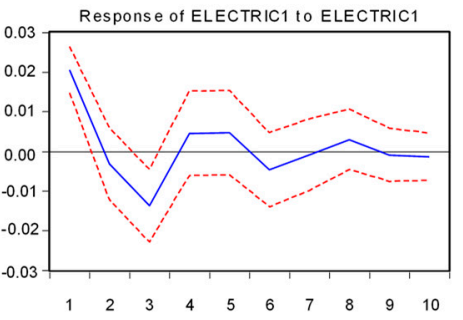

Response to Cholesky One S.D. Innovations \pm 2 S.E.
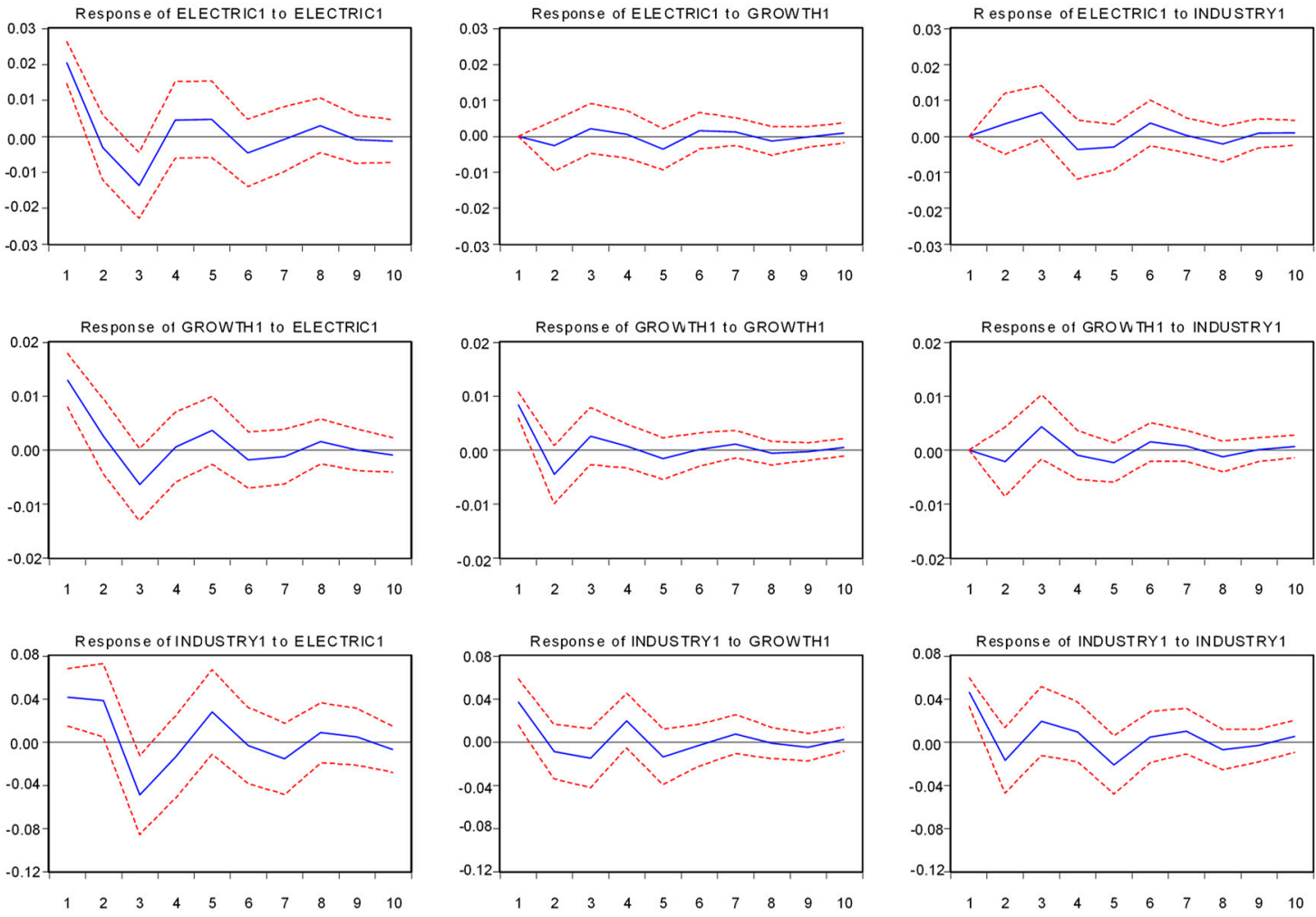

Figure A1. Impulse-Response Functions.

\section{References}

1. Ruiz-Real, J.L.; Uribe-Toril, J.; Valenciano, J.D.P.; Gázquez-Abad, J.C. Worldwide research on circular economy and environment: A bibliometric analysis. Int. J. Environ. Res. Public Health 2018, 15, 2699. [CrossRef]

2. Tonini, D.; Vadenbo, C.; Astrup, T.F. Priority of domestic biomass resources for energy: Importance of national environmental targets in a climate perspective. Energy 2017, 124, 295-309. [CrossRef]

3. Ajmi, A.N.; Hammoudeh, S.; Nguyen, D.K.; Sato, J.R. On the relationships between $\mathrm{CO}_{2}$ emissions, energy consumption and income: The importance of time variation. Energy Econ. 2015, 49, 629-638. [CrossRef] 
4. Steffen, B. The importance of project finance for renewable energy projects. Energy Econ. 2018, 69, $280-294$. [CrossRef]

5. Benton, R., Jr. Reduce, Reuse, Recycle ... and Refuse. J. Macromark. 2015, 35, 111-122. [CrossRef]

6. Kuo, P.H.; Huang, C.J. An electricity price forecasting model by hybrid structured deep neural networks. Sustainability 2018, 10, 1280. [CrossRef]

7. Johannesen, N.J.; Kolhe, M.; Goodwin, M. Relative evaluation of regression tools for urban area electrical energy demand forecasting. J. Clean. Prod. 2019, 218, 555-564. [CrossRef]

8. Qader, M.R. Electricity consumption and GHG emissions in GCC countries. Energies 2009, 2, 1201-1213. [CrossRef]

9. Salahuddin, M.; Alam, K. Information and Communication Technology, electricity consumption and economic growth in OECD countries: A panel data analysis. Int. J. Electr. Power Energy Syst. 2016, 76, 185-193. [CrossRef]

10. Kahouli, B. The causality link between energy electricity consumption, $\mathrm{CO}_{2}$ emissions, $\mathrm{R} \& \mathrm{D}$ stocks and economic growth in Mediterranean countries (MCs). Energy 2018, 145, 388-399.

11. Afzal, M.N.I.; Gow, J.; Rahman, A. Economic and Internet Growth Effect on Electricity Consumption in the BRICS Countries. Int. Adv. Econ. Res. 2019, 25, 339-346. [CrossRef]

12. Asumadu-Sarkodie, S.; Owusu, P.A. A multivariate analysis of carbon dioxide emissions, electricity consumption, economic growth, financial development, industrialization, and urbanization in Senegal. Energy Sour. Part B Econ. Plan Policy 2017, 12, 77-84. [CrossRef]

13. Liu, D.; Ruan, L.; Liu, J.; Huan, H.; Zhang, G.; Feng, Y.; Li, Y. Electricity consumption and economic growth nexus in Beijing: A causal analysis of quarterly sectoral data. Renew. Sustain. Energy Rev. 2018, 82, 2498-2503. [CrossRef]

14. Iyke, B.N. Electricity consumption and economic growth in Nigeria: A revisit of the energy-growth debate. Energy Econ. 2015, 51, 166-176. [CrossRef]

15. Mezghani, I.; Haddad, H.B. Energy consumption and economic growth: An empirical study of the electricity consumption in Saudi Arabia. Renew. Sustain. Energy Rev. 2017, 75, 145-156. [CrossRef]

16. Sbia, R.; Shahbaz, M.; Ozturk, I. Economic growth, financial development, urbanisation and electricity consumption nexus in UAE. Econ. Res.-Ekon. Istraž. 2017, 30, 527-549. [CrossRef]

17. Ibrahiem, D.M. Renewable electricity consumption, foreign direct investment and economic growth in Egypt: An ARDL approach. Procedia Econ. Financ. 2015, 30, 313-323. [CrossRef]

18. Churchill, S.A.; Ivanovski, K. Electricity consumption and economic growth across Australian states and territories. Appl. Econ. 2019, 1-13. [CrossRef]

19. Shahbaz, M.; Sarwar, S.; Chen, W.; Malik, M.N. Dynamics of electricity consumption, oil price and economic growth: Global perspective. Energy Policy 2017, 108, 256-270. [CrossRef]

20. Al-Mulali, U.; Che Sab, C.N.B. Electricity consumption, $\mathrm{CO}_{2}$ emission, and economic growth in the Middle East. Energy Sour. Part B Econ. Plan. Policy 2018, 13, 257-263. [CrossRef]

21. Karanfil, F.; Li, Y. Electricity consumption and economic growth: Exploring panel-specific differences. Energy Policy 2015, 82, 264-277. [CrossRef]

22. Zhang, C.; Zhou, K.; Yang, S.; Shao, Z. On electricity consumption and economic growth in China. Renew. Sustain. Energy Rev. 2017, 76, 353-368. [CrossRef]

23. Sarwar, S.; Chen, W.; Waheed, R. Electricity consumption, oil price and economic growth: Global perspective. Renew. Sustain. Energy Rev. 2017, 76, 9-18. [CrossRef]

24. Cowan, W.N.; Chang, T.; Inglesi-Lotz, R.; Gupta, R. The nexus of electricity consumption, economic growth and $\mathrm{CO}_{2}$ emissions in the BRICS countries. Energy Policy 2014, 66, 359-368. [CrossRef]

25. Bento, J.P.C.; Moutinho, V. $\mathrm{CO}_{2}$ emissions, non-renewable and renewable electricity production, economic growth, and international trade in Italy. Renew. Sustain. Energy Rev. 2016, 55, 142-155. [CrossRef]

26. Dyrstad, J.M.; Skonhoft, A.; Christensen, M.Q.; Ødegaard, E.T. Does economic growth eat up environmental improvements? Electricity production and fossil fuel emission in OECD countries 1980-2014. Energy Policy 2019, 125, 103-109. [CrossRef]

27. Awad, A.; Yossof, I. Electricity production, economic growth and employment nexus in Sudan: A cointegration approach. Int. J. Energy Econ. Policy 2016, 6, 6-13. 
28. Magalie, N.M.A.G.; Pacific, Y.K.T. Electricity production, Foreign Direct Investment, Government Effectiveness, and Economic Growth in Cameroon. East African Scholars J. Econo. Bus. Manag. 2018, 1, 13-20.

29. Vera, J.; Kristjanpoller, W. Granger causality between exports, economic growth and electricity production: Empirical evidence for Latin America. Lect. Econ. 2017, 86, 25-62. [CrossRef]

30. Sgobba, A.; Meskell, C. On-site renewable electricity production and self consumption for manufacturing industry in Ireland: Sensitivity to techno-economic conditions. J. Clean. Prod. 2019, 207, 894-907. [CrossRef]

31. Forsberg, C.W.; Stack, D.C.; Curtis, D.; Haratyk, G.; Sepulveda, N.A. Converting excess low-price electricity into high-temperature stored heat for industry and high-value electricity production. Electr. J. 2017, 30, 42-52. [CrossRef]

32. Mata-Torres, C.; Escobar, R.A.; Cardemil, J.M. Techno-economic analysis of CSP+ PV+ MED plant: Electricity and water production for mining industry in Northern Chile. In AIP Conference Proceedings; AIP Publishing: Melville, NY, USA, 2018; Volume 2033, p. 180007.

33. Morakabatchiankar, S.; Hjaila, K.; Graells, M.; Espuña, A. Developing a Multi-Objective Strategic-Tactical Optimization Model for Sustainable Production Supply Chains Considering Electricity Cogeneration: Sugar Cane Bioenergy Industry. In Computer Aided Chemical Engineering; Elsevier: Amsterdam, The Netherlands, 2017; Volume 40, pp. 2179-2184.

34. Tevdovski, D.; Petrevski, G.; Bogoev, J. The effects of macroeconomic policies under fixed exchange rates: A Bayesian VAR analysis. Econ. Res.-Ekon. Istraž. 2019, 32, 2138-2160. [CrossRef]

35. Chan, J.C.; Jacobi, L.; Zhu, D. How sensitive are VAR forecasts to prior hyperparameters? An automated sensitivity analysis. Top. Identif. Ltd. Depend. Var. Partial Obs. Exp. Flex. Model. Part A (Adv. Econ.) 2019, 40, 229-248.

36. Afonso, A.; Baxa, J.; Slavík, M. Fiscal developments and financial stress: A threshold VAR analysis. Empir. Econ. 2018, 54, 395-423. [CrossRef]

37. Jasper, J. A Var Analysis of the Connection between FDI and Economic Growth: A Case Study from Vietnam after 30 Years Reforms. Int. J. Innov. Econ. Dev. 2019, 4, 51-67. [CrossRef]

38. Gnimassoun, B.; Mignon, V. How do macroeconomic imbalances interact? Evidence from a panel VAR analysis. Macroecon. Dyn. 2016, 20, 1717-1741. [CrossRef]

39. Pardon, M.H.; Barouni, M.; Golestani, S. Dynamic Analysis of the effect of Corruption on Health Indices in Selected Countries using Panel VAR Model. J. Health Dev. 2015, 4, 181-189.

40. Charfeddine, L. Breaks or long range dependence in the energy futures volatility: Out-of-sample forecasting and VaR analysis. Econ. Model. 2016, 53, 354-374. [CrossRef]

41. Kabir, M. Determinants of life expectancy in developing countries. J. Dev. Areas 2008, 41, 185-204. [CrossRef]

42. Monsef, A.; Mehrjardi, A.S. Determinants of life expectancy: A panel data approach. Asian Econ. Financ. Rev. 2015, 5, 1251-1257. [CrossRef]

43. Martín Cervantes, P.A.; Rueda López, N.; Cruz Rambaud, S. A Causal Analysis of Life Expectancy at Birth. Evidence from Spain. Int. J. Environ. Res. Public Health 2019, 16, 2367. [CrossRef] [PubMed]

44. Mardani, A.; Jusoh, A.; Zavadskas, E.K.; Cavallaro, F.; Khalifah, Z. Sustainable and renewable energy: An overview of the application of multiple criteria decision making techniques and approaches. Sustainability 2015, 7, 13947-13984. [CrossRef]

45. Zhao, H.; Guo, S. External benefit evaluation of renewable energy power in China for sustainability. Sustainability 2015, 7, 4783-4805. [CrossRef]

46. Uribe-Toril, J.; Ruiz-Real, J.L.; Milán-García, J.; De Pablo Valenciano, J. Energy, Economy, and Environment: A Worldwide Research Update. Energies 2019, 12, 1120. [CrossRef]

C 2019 by the authors. Licensee MDPI, Basel, Switzerland. This article is an open access article distributed under the terms and conditions of the Creative Commons Attribution (CC BY) license (http://creativecommons.org/licenses/by/4.0/). 